\title{
NASLJEDNOPRAVNA RASPOLAGANJA U KORIST ŽIVOTINJE
}

Sažetak: $\quad U$ ovom radu istražit će se mogućnosti pravnih raspolaganja u korist životinje za slučaj smrti. Ovakve tendencije javljaju se u suvremenim pravnim porecima $i$ pitanje je trenutka kada će doći do potrebe njihove pravne regulacije i u hrvatskom nasljednom pravu. Analizirani su instituti nasljednog prava de lege lata koji mogu predstavljati mehanizam raspolaganja imovinom u korist životinje za slučaj ostaviteljeve smrti. Predlaže se intervencija zakonodavca u Zakon o nasljeđivanju i Zakon o zakladama koja bi omogućila formiranje oporučne zaklade u korist ljudskog korisnika dok bi upravitelj zaklade vršio dodjelu sredstava korisniku za pokriće troškova koje korisnik zaklade ima za skrb nad životinjom.

Ključne riječi: $\quad$ nasljedno pravo, nalog, zaklada, životinja, kućni ljubimac, oporuka

\section{UVOD}

Pravni položaj nasljednika uređuje objektivno nasljedno pravo, ${ }^{1}$ na temelju kojeg se pojedinim osobama priznaje status nasljednika i subjektivna prava koja iz toga proizlaze. U suvremenim pravnim porecima, u pravilu, nema osoba koje bi bile apsolutno nesposobne biti nasljednikom. Tako je i u suvremenom hrvatskom pravu u kojem se sposobnost za nasljeđivanje podudara s općom pravnom sposobnošću. ${ }^{2}$ Međutim, takvo uređenje posljedica je dugotrajnog razvoja kulture i pravne svijesti društva. Naime, u relativno bliskoj prošlosti cijelim kategorijama ljudi bilo je onemogućeno da nasljeđuju. ${ }^{3}$ Imovina je nekada, prije svega, pripadala kolektivu, no kako se položaj pojedinca mijenjao, pravo počinje kao nasljednika percipirati one

\footnotetext{
* Dr. sc. Davorin Pichler, docent, Pravni fakultet Sveučilišta Josipa Jurja Strossmayera u Osijeku, Stjepana Radića 13, 31000 Osijek. Adresa e-pošte: dpichler@pravos.hr. ORCID: https://orcid.org/0000-0002-0068-3601.

1 Gavella, Nikola, Belaj, Vlado, Nasljedno pravo, Narodne novine, Zagreb, 2008., str. 83.

$2 \quad$ Ibid., str. 92.

3 Tako su zajedničkom baštinom, kod Rimljana, povezani članovi rimskog roda, gensa, pa je svoju gentilsku vezu imao dokazati onaj koji je podizao nasljedne zahtjeve. Milić, Ivo, Oko postanka oporuke, Jugoslavenska akademija znanosti i umjetnosti, Zagreb, 1951., str. 10.-11.
} 
članove obitelji koji su s ostaviteljem u najužim obiteljskim vezama. ${ }^{4}{ }^{5}$ Krug osoba koje imaju pravo na nasljeđivanje ostavitelja različit je u svakom pravnom poretku što ovisi o različitom shvaćanju obitelji i obiteljskih odnosa ${ }^{6}$ u određenom društvu. Načelo dispozitivnosti, kao opće načelo građanskog prava, na području uređenja nasljeđivanja dolazi do izražaja u mogućnosti da svatko sa svim što mu pripada raspolaže za slučaj svoje smrti. To načelo se, u nasljednom pravu, zrcali u slobodi oporučnog raspolaganja. Međutim, kao i ostala načela građanskog i nasljednog prava i ono nije neograničeno. Pravni poredak postavlja ograničenja slobodi oporučnog raspolaganja u obliku instituta nužnog nasljednog prava. Nužno nasljedno pravo striktnim normama nekim članovima obitelji jamči da će ostvariti barem nužni dio iz ostavine, makar to bilo i u suprotnosti s pravnim raspolaganjima ostavitelja. ${ }^{7}$ Tendencije suvremenih pravnih poredaka prema suženju kruga zakonskih nasljednika, ograničavanju oporučnih raspolaganja ostavitelja u korist nužnih nasljednika kao i odbacivanja mogućnosti nasljeđivanja na osnovi ugovora imaju za posljedicu reformiranje načela dispozitivnosti i činjenicu da pravni poredak na sebe preuzima ulogu onoga koji će odrediti sudbinu i svrhu ostaviteljevih pravnih dobara nakon njegove smrti. Ovo ograničavanje temelji se na pretpostavci da je ostavitelj bio u najčvršćim obiteljskim i emotivnim odnosima s osobama koje su mu i biološki i socijalno najbliže. Naravno da stvarnost za svakog pojedinca može biti dijametralno suprotna. Individualizam današnjice traži da razmotrimo i neke druge mogućnosti u raspolaganju imovinom za slučaj smrti pojedinca.

Socijalne i emotivne veze koje suvremeni čovjek razvija prema životinjama, posebno kućnim ljubimcima, evoluirale su tijekom stoljeća. Ne treba bježati od činjenice da u uvjetima suvremenog otuđenja čovjeka životinja sve više počinje zavrjeđivati epitet najboljeg čovjekova prijatelja. U tom smislu, u ovom radu, istražit će se mogućnosti pravnih raspolaganja u korist životinje za slučaj smrti. Ovakve tendencije javljaju se u suvremenim pravnim porecima ${ }^{8}$ i pitanje je trenutka kada će doći do potrebe njihove pravne regulacije i u hrvatskom nasljednom pravu.

$4 \quad$ Gavella et al., op. cit. (bilješka 1), str. 189.

5 U najstarije doba, u rimskom pravu, nasljeđivanje se zapravo svodilo na zamjenu porodičnog starješine (pater familias), čiju bi funkciju u slučaju smrti preuzeo sin (filius familias), njegov prvi suradnik i svojevrsni suvlasnik, zadržavši svu porodičnu imovinu i druga prava koja je imao umrli. Za pojam nasljednika rimski su pravnici upotrebljavali pojam heres. Zanimljivo je da se riječ heres u latinskom jeziku pojavljuje samo u muškom rodu, što može ukazivati na okolnost da je ostavina u najstarije doba pripadala načelno jedino muškarcima. Razvitak proizvodnje i, usporedo s time, raspadanje starinske rimske porodične zajednice odrazili su se na području nasljednog prava. Ulogu reformatora odigrao je pretor, a poslije i imperatori koji dopuštaju širu primjenu načela kognacije (srodstva po krvi), posebno u odnosima majke i djece. Romac, Ante, Rimsko pravo, Narodne novine, Zagreb, 1992., str. 359.-362.

6 Gavella et al., op. cit. (bilješka 1), str. 191.

7 Ibid., str. 217.

8 Tako u dvadesetom stoljeću, koje možemo označiti i kao altruističku fazu u građanskopravnom tretmanu životinja, razvija se stav da je životinja vrijednost sama po sebi, a ne samo vrijednost za čovjeka. Time se proširuje pravni pristup životinji kao subjektu prava opremljenom pravnom sposobnošću i vlastitim pravima. Vodinelić, V. Vladimir, Građansko pravo - Uvod u građansko pravo i Opšti deo građanskog prava, Pravni fakultet Univerziteta Union u Beogradu, Beograd, 2012., str. 412.-413. 


\section{STATUS ŽIVOTINJE U GRAĐANSKOM I NASLJEDNOM PRAVU}

Prevladavajuće shvaćanje u domaćoj i međunarodnoj pravnoj teoriji jest da se životinje smatraju pravnim objektima, odnosno stvarima ${ }^{9},{ }^{10}$. U tom smislu, i u Republici Hrvatskoj životinja je izjednačena sa stvari, pa njezin status utvrđuje čl. 2. Zakona o vlasništvu i drugim stvarnim pravima ${ }^{11}$ koji navodi da su stvari tjelesni dijelovi prirode, različiti od ljudi, koji služe ljudima za uporabu. Uzima se da su stvari i sve drugo što je zakonom s njima izjednačeno. Međutim, unatoč tome što ne daju životinjama status subjekta prava, pravni sustavi životinjama garantiraju zaštitu određenih pravnih dobara među kojima su život, zdravlje i dobrobit. Takvu zaštitu u Republici Hrvatskoj određuje Zakon o zaštiti životinja, ${ }^{12}$ te Kazneni zakon ${ }^{13}$ sankcioniranjem mučenja ili ubijanja životinja.

Njemački zakonodavac išao je i korak dalje. Paragraf 90.a Njemačkog građanskog zakoni$\mathrm{ka}^{14}$ određuje da "životinje nisu stvari, nego ih se zaštićuje posebnim propisima. Na njih će se primijeniti propisi koji se odnose na stvari, ako nije što drugo određeno”. Paragraf 903. BGB-a određuje da: "vlasnik stvari može, ako se tome ne protive zakon ili prava trećih osoba, sa stvari činiti što ga je volja i iz toga isključiti bilo čiji utjecaj. Vlasnik životinje pri izvršavanju svojih ovlasti mora poštovati posebne propise o zaštiti životinja." ${ }^{15}$

Austrijski Građanski zakonik ${ }^{16}$ u $§ 285$. određuje da se "smatra stvari sve ono što se razlikuje od osobe i služi ljudima za upotrebu". Paragraf 285.a ABGB-a određuje da "životinje nisu stvari, nego se one štite na temelju posebnih propisa. Propisi koji su važeći za stvari samo su toliko primjenjivi i na životinje ako ne postoji drukčijih (odstupajućih) pravila”. ${ }^{17}$ Iako Engleska i Sjedinjene Američke Države predstavljaju rodonačelnike pokreta za zaštitu životinja, u njima također životinja ne predstavlja pravni subjekt, nego je i dalje objekt prava. ${ }^{18},{ }^{19} \mathrm{Me}-$

9 "U novije doba neki pravni sustavi odustaju od tradicionalnog shvaćanja po kojem su životinje jednako sposobne biti objekti stvarnih prava kao bilo koje druge stvari (stvari koje se same kreću - res moventes, među koje se nekada ubrajalo i robove)". Gavella, Nikola, Josipović, Tatjana, Gliha, Igor, Belaj, Vlado, Stipković, Zlatan, Stvarno pravo, Narodne novine, Zagreb, 2007. str. 70 . slobodno u prirodi i bile tretirane kao res nullius pa ih je svatko mogao uloviti i tako steći vlasništvo i one koje su bile pripitomljene. Za pripitomljene životinje uzimalo se da pripadaju vlasniku sve dok imaju naviku vraćati se kući (animus revertendi), ali čim to prestanu raditi, opet postaju res nullius. Romac, Ante, Rječnik rimskog prava, Informator, Zagreb, 1989., str. 32.

11 Zakon o vlasništvu i drugim stvarnim pravima, Narodne novine, broj 91/1996, 68/1998, 137/1999, 22/2000, 73/2000, 129/2000, 114/2001, 79/2006, 146/2008, 38/2009, 143/2012, 152/2014 81/2015 (pročišćeni tekst), 94/2017 (pročišćeni tekst), u daljnjem tekstu ZV.

Zakon o zaštiti životinja, Narodne novine, broj 102/2017, u daljnjem tekstu ZZŽ.

Kazneni zakon, Narodne novine, broj 125/2011, 144/2012, 56/2015, 61/2015, 101/2017.

15 BGB, op. cit. (bilješka 14).

16 Allgemeines bürgerliches Gesetzbuch, JGS, Nr. 946/1811, u daljnjem tekstu ABGB.

17 ABGB, op. cit. (bilješka 16).

18 Zakon u Sjedinjenim Američkim Državama određuje domaće životinje kao privatno vlasništvo. Bearup, J. Brooke, Pets: Property and the Paradigm of Protection, Journal of Animal Law, Vol. III, Michigan State University College of Law, 2007., str. 177.

19 Pravni okvir Sjedinjenih Američkih Država u odnosu na pravo vlasništva proizlazi iz common lawa. Prema common lawu, životinje se smatraju privatnim vlasništvom. Roukas, S. Marcella, Determining the Value of Companion Animals in Wrongful Harm or Death Claims: A Survey of U. S. Decisions and Legislative Proposal in Florida to Authorize Recovery for Loss of Companionship, Journal of Animal Law, 3, Michigan State University College of Law, 2007., str. 47. 
đutim, posljednjih godina može se primijetiti da se u nekim pravnim odnosima (prije svega prema kućnim ljubimcima) životinje shvaćaju kao objekti sui generis, ${ }^{20}$ odnosno kao vrijedna bića s emocijama u odnosu na koje čovjek ima ekonomske, afektivne, estetske i druge interese i dužnosti, pa zbog toga ih pravni poredak zaštićuje više od ostalih pravnih objekata. Ova tendencija priznavanja povoljnijeg statusa životinja mogla bi predstavljati prijelaz $\mathrm{k}$ unaprjeđenju životinja u subjekte prava, a njihovu zaštitu u životinjska prava ${ }^{21},{ }^{22},{ }^{23}$. U odnosu na sam pojam životinje, u pravilu, vrši se temeljna podjela na divlje i domaće životinje. Tako i ZZŽ u čl. 4. st. 1. t. 4. određuje da su "divlje životinje sve životinje osim domaćih životinja, kućnih ljubimaca, službenih životinja i radnih životinja”. ${ }^{24}$ Domaće životinje su, na temelju ZZŽ-a, “životinje koje je čovjek pripitomio i udomaćio i koje uzgaja radi proizvodnje hrane, hrane za životinje i nusproizvoda životinjskog podrijetla koji nisu za prehranu ljudi te u druge gospodarske svrhe". ${ }^{25}$ Kućni ljubimci su, prema odredbama istog propisa, "životinje koje čovjek drži zbog društva, zaštite i pomoći ili zbog zanimanja za te životinje". ${ }^{26}$ Slična distinkcija postoji i u drugim pravnim sustavima. ${ }^{27}$ Kao potkategorija domaće životinje postoji i "životinja pratilac” (companion animal) imatelj koje ima i više obveza glede skrbi za nju. ${ }^{28} \mathrm{U}$ tom smislu postoje i prijedlozi da se potkategoriji "životinji pratiocu" prizna "pravo da ne bude vlasništvo", odnosno status "quasi-osobe”, tj. neki oblik pravne osobnosti. ${ }^{29},{ }^{30}$ Ovi prijedlozi uključuju implementaciju sustava "skrbnika životinje". U tom sustavu, životinja bi, slično statusu djeteta, bila samostalna i samo u posjedu i pod kontrolom čovjeka koji bi zastupao njezine pravne interese i pružao zaštitu.

20 Može se istaknuti i stav da su životinje i objekti i subjekti prava, ali u oba svojstva specifični, različiti od ostalih subjekata i objekata prava. Kad je riječ o osobnim pravima (npr. životinja može imati pravo na ime, život, zdravlje fizički i psihički integritet i dr.), onda su subjekti prava, a u drugom pogledu su i objekti prava, i to objekti prava vlasništva, zakupa i drugih imovinskih prava, što ljudi i pravne osobe nisu. Vodinelić, op. cit. (bilješka 8), str. 415.

21 Visković, Nikola, Angloamerički animal law, Zbornik radova Pravnog fakulteta u Splitu, 2/1993., 457.- 458.

22 Pravo životinja je nova pravna grana i u literaturi se, u objektivnom smislu, definira kao skup pravnih pravila kojima se regulira postupanje ljudi prema životinjama i osigurava zaštita njihove dobrobiti. Stojanović, Nataša, Pravo životinja, Pravni fakultet Univerziteta, Centar za publikacije, Niš, 2017., str. 7.

23 U tom smjeru je i Republika Hrvatska prihvatila novi ZZŽ koji je usklađen s propisima EU-a što je, uz potrebu donošenja novog zakona zbog nemogućnosti donošenja podzakonskih propisa kojima se štite život, zdravlje i dobrobit životinja u skladu s trenutačno važećim spoznajama, bio glavni razlog donošenja novog zakona kojim se štiti cjelokupni životinjski integritet. Tako npr. ZZŽ taksativno navodi slučajeve kada je životinju moguće usmrtiti i pod kojim uvjetima te predviđa velik broj prekršajnih odredbi koje sankcioniraju nepridržavanje obveza koje je ZZŽ odredio fizičkim i pravnim osoba u cilju zaštite dobrobiti životinja. Nedić, Tomislav, Pravni sustav zaštite života, zdravlja - bioetički pristup u pravnom okviru, Socijalna ekologija: časopis za ekološku misao i sociologijska istraživanja okoline, Vol. 27, No. 1, 2018., str. 81.-83. ZZŽ, op. cit. (bilješka 12).

25 Članak 4. st. 1. t. 6. ZZŽ-a, op. cit. (bilješka 12).

26 Članak 4. st. 1. t. 10. ZZŽ-a, op. cit. (bilješka 12).

27 Dvije kategorije za životinje, na temelju common lawa, jesu divlje i domaće. Roukas, op. cit. (bilješka 19), str. 48.

28 Ibid., str. 49.

29 Foster, H. Frances, Should Pets Inherit?, Florida Law Review, Vol. 63, Issue 4, 2011., str. 841.-842., https://scholarship.law.ufl. edu/cgi/viewcontent.cgi?referer=https://www.google.hr/\&httpsredir=1\&article=1094\&context=flr, pristupljeno 4 . listopada 2018.

30 Kao argumente za priznavanje pravnog subjektiviteta životinjama navodi se da nositelji prava mogu biti i bića koja ne odlikuje razum (maloumne osobe, začet a nerođen čovjek), neka prava se vrše sama od sebe (jer su prava stanja, a ne prava radnji), traženje zaštite za ta prava može se organizirati preko posebnih tijela (npr. u kantonu Zürich postoji državno tijelo za zaštitu životinja u kaznenim predmetima). Također, ističe se da pravni poredak ima i formativnu ulogu, da stvara svijest o potrebi priznavanja prava, a i primjena normi doprinosi formiranju pravne svijesti. Vodinelić, op. cit. (bilješka 8), str. 414.-415. 
Štoviše, predlaže se uvođenje životinjskog pravobranitelja (ombudsman) koji bi zastupao prava i dobrobit životinja. ${ }^{31}$

\section{NAČELA I INSTITUTI HRVATSKOG NASLJEDNOPRAVNOG UREĐENJA}

Nasljednopravno uređenje u Republici Hrvatskoj, nakon gotovo pedeset godina, ${ }^{32}$ izmijenjeno je 2003. godine donošenjem Zakona o nasljeđivanju. ${ }^{33}$ Predmet analize u ovom radu bit će odredbe $\mathrm{ZN}-a$ koje uređuju načela i institute nasljednog prava od značaja za temu rada. U tom smislu, važno je načelo slobode raspolaganja za slučaj smrti, instituti osoba nasljednika (zakonskog i oporučnog), naloga, zaklade (samostalne i nesamostalne) te ugovori koji se odnose na nasljeđivanje ili se sklapaju u vezi s nasljeđivanjem.

\subsection{NAČELO SLOBODE RASPOLAGANJA ZA SLUČAJ SMRTI}

Već je istaknuto da se načelo dispozitivnosti, kao opće načelo građanskog prava, na području nasljednog prava izražava u mogućnosti da svatko sa svim što mu pripada raspolaže za slučaj svoje smrti. Međutim, kao i ostala načela građanskog i nasljednog prava ni ono nema apsolutan značaj. Načelo je ograničeno institutom nužnog nasljednog prava, ali i načelno negativnim stavom nasljednog prava prema ugovorima s nasljednopravnim učinkom. Ova ograničenja prisutna su kako u našem tako i u drugim pravnim porecima, kako kontinentalnoeuropskog tako i common law pravnog sustava. Međutim, pravna teorija počinje ukazivati na činjenicu da privilegiranjem članova "tradicionalne" obitelji nasljedno pravo vrši sistematsku diskriminaciju na temelju rase, etniciteta, roda, društvene klase i seksualnosti. Ta diskriminacija toliko prožima nasljedno pravo da čini takozvani organizacijski princip nasljednog prava - slobodu disponiranja - mitom. ${ }^{34}$ U opsežnoj i rastućoj literaturi utvrđuje se obiteljski obrazac kao zastario, isključujući i diskriminatoran. Ukazuje se da obiteljska paradigma koja nagrađuje "zakonske bračne drugove i djecu iz braka" rapidno nestaje. ${ }^{35}$ Tako američki znanstvenici ukazuju da što više Amerikanaca pronalazi privrženost i potporu izvan nuklearne obitelji, obiteljska paradigma isključuje one koji bi trebali naslijediti i čiji su životi najintimnije povezani

31 Bearup, op. cit. (bilješka 18), str. 186.-187.

32 Dotad je na snazi bio propis iz 1955. godine, također s nazivom Zakon o nasljeđivanju, Službeni list FNRJ, broj 20/1955, Službeni list SFRJ, broj 12/1965, 42/1965 - pročišćeni tekst, 44/1965 i 47/1965, Narodne novine, broj 52/1971, 52/1973, 47/1978. 
s ostaviteljem. ${ }^{36}$ Ograničenje raspolaganja za slučaj smrti uvjetovano je i zakonskim definiranjem instituta osobe nasljednika.

\subsection{OSOBE NASLJEDNIKA}

ZN u čl. 4. st. 2. određuje da je: "svaka osoba sposobna naslijediti ako zakonom nije što drugo određeno". ${ }^{37},{ }^{38}$ Pojam "osoba" ima značenje pravnoga subjekta. Kao pravni subjekt u građanskopravnim odnosima pojavljuje se čovjek pojedinac te pravna osoba. ${ }^{39}$ Zakon o obveznim odnosima ${ }^{40} \mathrm{u}$ čl. 17. st. 1 . određuje da "svaka fizička i pravna osoba je sposobna biti nositeljem prava i obveza, odnosno određuje svojstvo pravne sposobnosti”. Na temelju ovakvog zakonskog uređenja, životinja ne predstavlja pravni subjekt te ne bi mogla biti ni oporučni nasljednik ni zapisovnik (legatar). ${ }^{41}$ Postavlja se pitanje kojim institutima nasljednog prava, de lege lata, moguće je raspolagati imovinom u korist životinje. ${ }^{42} \mathrm{U}$ tom smislu, u radu ćemo se usredotočiti na institute oporučnog naloga, samostalne i nesamostalne zaklade te ugovora o nasljeđivanju i u vezi s nasljeđivanjem.

\subsection{NALOG (MODUS)}

Osobama kojima nešto ostavlja oporučitelj, određivanjem naloga, može odrediti dužnost ispuniti činidbu na temelju vrijednosti onoga što stječu na temelju oporučiteljeva raspolaganja. ${ }^{43} \mathrm{U}$ pravnoj se teoriji smatra da je nalog nuzgredna odredba koja se dodaje besplatnom pravnom poslu ${ }^{44}$ i u tom smislu općenito služi prilagođavanju i modifikaciji pravnih poslova konkretnim prilikama. Za razliku od zapisa, nalog ne daje korisniku naloga pravo da od opterećene osobe zahtijeva činidbu. ${ }^{45} \mathrm{U}$ tom smislu, nalog ne predstavlja efikasan mehanizam ostvarivanja posljednje volje ostavitelja. Ako bi ostavitelj, naprimjer, ostavio nalogom odre-

36 Foster, H. Frances, The Family Paradigm of Inheritance Law, North Carolina Law Review, Vol. 80, No. 1, 2001., str. 242., https:// scholarship.law.unc.edu/cgi/viewcontent.cgi? referer= https:// www.google.hr/\&httpsredir =1\&article=3967\&context=nclr, pristupljeno 4. listopada 2018.

ZN, op. cit. (bilješka 33).

列 nitko nije zbog smrti ostavitelja stekao subjektivno nasljedno pravo, ni na temelju zakona ni na temelju oporuke, ostavina će prijeći na javnopravne subjekte, tj. kako određuje čl. 20. ZN-a na općinu odnosno grad. ZN, op. cit. (bilješka 33).

Klarić, Petar, Vedriš, Martin, Građansko pravo, Narodne novine, Zagreb, 2006., str. 32. Zakon o obveznim odnosima, Narodne novine, broj 35/2005, 41/2008, 125/2011, 78/2015, 29/2018, u daljnjem tekstu ZOO.

Članak 45. ZN-a određuje zapisovnika "kao osobu koja je ovlaštena da od nasljednika ili druge osobe u čiju je korist oporučitelj oporučno raspolagao zahtijeva neko davanje, činjenje, trpljenje ili propuštanje njemu ili nekoj drugoj osobi”. ZN, op. cit. (bilješka 33).

U smislu ovoga rada, raspolaganje imovinom bit će shvaćeno u najširem smislu, odnosno, u mjeri, na način i u cilju ostvarivanja sredstava za potrebnu skrb za životinju nakon smrti njezina vlasnika. 
đena sredstva određenoj osobi koja bi se skrbila za životinju nakon smrti oporučitelja, ona nema zakonsku mogućnost tražiti ispunjenje naloga od osobe opterećene nalogom. ${ }^{46}$ Članak 48. st. 1. ZN-a određuje da će se "nalog smatrati raskidnim uvjetom, tako da osoba opterećena nalogom gubi ono što joj je namijenjeno ako ne ispuni nalog”. ${ }^{47}, 48$ Zakonski mehanizam ostvarivanja oporučiteljeve volje preko naloga mogao bi se primijeniti za slučajeve kada oporučitelj želi npr. odrediti dužnost brige i uzdržavanja za svoga kućnog ljubimca (ili drugu životinju) osobi kojoj ostavlja neku korist iz ostavine. "Oblik naloga ima i oporučna odredba o tzv. nesamostalnoj zakladi." 49

\subsection{ZAKLADE}

Članak 46. st. 1. ZN-a predviđa mogućnost da oporučitelj oporukom odredi da se "neka stvar ili pravo ili dio ili cijela ostavina upotrijebi za postignuće neke dopuštene svrhe". ${ }^{50} \mathrm{U}$ tom slučaju riječ je o tzv. nesamostalnoj zakladi. Nesamostalna zaklada nije pravni subjekt, nego pripada određenoj fizičkoj ili pravnoj osobi. "Ona predstavlja poseban fond imovine koji je ta osoba dužna koristiti isključivo u svrhu koju je odredio oporučitelj." ${ }^{51} \mathrm{U}$ tom smislu, oporučitelj određenu imovinu može namijeniti npr. u korist skrbi za određenu životinju.

Kako bi ostvario mogućnost ispunjenja određene trajnije svrhe svojim oporučnim raspolaganjem, oporučitelj može, na temelju čl. 46. st. 2. ZN-a odrediti osnivanje i samostalne zaklade. Citirani članak određuje da "ako je oporučitelj odredio osnivanje zaklade i namijenio sredstva za postignuće njezine svrhe, zaklada će nastati kada se ispune pretpostavke određene posebnim propisima o zakladama". ${ }^{52}$ Poseban propis koji uređuje osnivanje, ustrojstvo, djelatnost i prestanak zaklada je Zakon o zakladama. ${ }^{53}$ Treba naglasiti da ZOZ predstavlja recentnu intervenciju zakonodavca u uređenje, osnivanja i djelovanja zaklada. Naime, ZOZ stupa na snagu 1. ožujka 2019. godine, a dotada u primjeni je Zakon o zakladama i fundacijama, ${ }^{54}$ propis koji je ovo područje regulirao 24 godine. Međutim, u odnosu na pitanja od značaja za temu ovoga rada nema bitnije razlike u načinu uređenja između ovih dvaju zakona. Različiti pristupi u zakonskoj regulaciji, po potrebi, bit će komparativno istaknuti u nastavku rada.

Oporučna odredba kojom bi se odredilo osnivanje zaklade pravni je temelj za osnivanje zaklade. Članak 7. st. 1. ZOZ-a određuje da je "zaklada osnovana donošenjem akta o osnivanju

46 Kontrec, Damir, Matko-Ruždjak, Jožica, Sessa Đuro, Zakon o nasljeđivanju s komentarima, poveznicama, sudskom praksom, prilozima, primjerima i abecednim kazalom pojmova, Organizator, Zagreb, 2005., str. 75.

47 ZN, op. cit. (bilješka 33).

48 Ispunjenje naloga može zahtijevati oporučiteljev nasljednik (odnosno, bilo koji od sunasljednika), odnosno, ako postoji, izvršitelj oporuke. Gavella et al., op. cit. (bilješka 1), str. 167.

Klarić et al., op. cit. (bilješka 39), str. 745.

50 ZN, op. cit. (bilješka 33).

51 Gavella et al., op. cit. (bilješka 1), str. 169.

52 ZN, op. cit. (bilješka 33).

53 Zakon o zakladama, Narodne novine, broj 106/2018, u daljnjem tekstu ZOZ. 
zaklade odnosno proglašenjem oporuke kad se zaklada osniva oporukom". ${ }^{55}$ Pravnu osobnost zaklada stječe danom upisa u Registar zaklada Republike Hrvatske. ${ }^{56}$

I ZZF imao je slično uređenje na temelju kojega je pravni temelj za osnivanje zaklade bila oporučna odredba kojom se određuje osnivanje zaklade, a koja će nastati kada i ako od nadležnog tijela javne vlasti dobije odobrenje i bude registrirana. Osnivanje tada djeluje ex tunc, tj. kao da je u trenutku smrti oporučitelja zaklada već postojala. U suprotnom zaklada ne bi mogla postati nasljednikom. ${ }^{57}, 58,59$

ZOZ određuje da oporuka kojom se osniva zaklada mora "sadržavati odredbe o svrsi zaklade te očitovanje volje zakladnika da se određena imovina namjenjuje za osnivanje zaklade. Ako u oporuci nije naznačen izvršitelj oporuke koji je zadužen za upis zaklade, odredit će ga javni bilježnik ili nadležni sud". 60

Međutim, ZOZ u čl. 2. st. 1. određuje da je "zaklada imovina namijenjena da služi ostvarivanju neke općekorisne ili dobrotvorne svrhe” ${ }^{61}, 62$ Kao općekorisnu svrhu ZOZ određuje onu svrhu "ispunjavanjem koje se unapređuju građanska i ljudska prava i slobode, demokratske institucije društva, razvoj društva i lokalnih zajednica, zaštita okoliša i prirode i održivi razvoj, međunarodna razvojna pomoć i suradnja te kulturna, prosvjetna, znanstvena, duhovna, športska, zdravstvena, humanitarna, socijalna ili koja druga društvena djelatnost kojom se promiče opća korist i djelovanje za opće dobro i pridonosi ostvarivanju najviših vrednota ustavnog poretka Republike Hrvatske". Kao dobrotvornu svrhu ZOZ određuje onu svrhu ispunjenjem koje se pruža potpora osobama kojima je potrebna pomoć. "Svrha je zaklade općekorisna, odnosno dobrotvorna i ako se tiče samo osoba koje pripadaju određenom pozivu, nacionalnoj, društvenoj, jezičnoj, kulturnoj, znanstvenoj i vjerskoj grupi ili slično, osoba koje povezuju iste zdravstvene, socijalne, kulturne i slične potrebe i interesi odnosno osoba koje žive na određenom području ili su obuhvaćene djelatnošću određene udruge, ustanove ili druge pravne osobe" ${ }^{63},{ }^{64} \mathrm{Iz}$ dikcije čl. 3. ZOZ-a može se zaključiti da ne bi bilo moguće osnivanje zaklade u cilju da se imovina ostavitelja namjeni skrbi i uzdržavanju individualno određene životinje budući da se time ne unaprjeđuje određena društvena djelatnost, odnosno materijalno stanje društva. Također, ZOZ kao dobrotvornu svrhu određuje samo onu kojom se potpora

55 ZOZ, op. cit. (bilješka 53).

56 Zaklade se upisuju u registar zaklada pri uredima državne uprave u županiji, odnosno gradskom uredu Grada Zagreba nadležnom za poslove opće uprave, prema sjedištu zaklade. Zaklada svoju djelatnost počinje obavljati upisom u registar zaklada. Članak 16. st. 1. i čl. 17. st. 8. ZOZ-a, op. cit. (bilješka 53).

57 Gavella et al., op. cit. (bilješka 1), str. 170.

58 Fundacija se od zaklade razlikuje po tome što se osniva na razdoblje ne dulje od pet godina. Klarić et al., op. cit. (bilješka 39), str. 55.

I ZOZ u čl. 5. st. 2. predviđa mogućnost osnivanja zaklade na određeno vrijeme dok se ne ispuni svrha zaklade. ZOZ, op. cit. (bilješka 53).

60 Članak 8. st. 1. i 2. ZOZ-a, op. cit. (bilješka 53).

61 ZOZ, op. cit. (bilješka 53).

62 Članak 7. traži da određenje svrhe zaklade sadrži i akt o osnivanju zaklade, dok čl. 8. traži da odredbe o svrsi zaklade mora sadržavati oporuku kojom se osniva zaklada. ZOZ, op. cit. (bilješka 53).

63 Članak 3. ZOZ-a, op. cit. (bilješka 53). 
pruža osobama. Kao što je rečeno, prema de lege lata uređenju u našem pravnom poretku životinje nemaju status subjekta prava. ${ }^{65}$

\subsubsection{Komparativni prikaz uređenja raspolaganja ostavinom u korist životinje preko mehanizam zaklade}

Kao što je istaknuto, Sjedinjene Američke Države predstavljaju rodonačelnike pokreta za zaštitu životinja. Međutim, i u Sjedinjenim Američkim Državama životinja ne predstavlja pravni subjekt, nego još uvijek objekt prava. Upravo zbog činjenice da su Amerikanci ekstremno posvećeni svojim kućnim ljubimcima ${ }^{66}$ u Sjedinjenim Američkim Državama razvija se intenzivna zakonodavna i sudska djelatnost koja prihvaća nove pristupe u regulaciji raspolaganja imovinom ostavitelja u korist životinje.

Upravo zbog toga, izabran je common law trust kao institut pravnog sustava Sjedinjenih Američkih Država za objekt komparativnog prikaza. Institut trust ima veliki praktični značaj $\mathrm{u}$ angloameričkom pravnom sustavu, prilagodljivost i verzatilnost u uređenju različitih društvenih odnosa. Također, relativno nedavne zakonske intervencije omogućile su da trust postane prikladan instrument za imovinska raspolaganja u korist životinje. U tom smislu, de lege ferenda, ideje iz angloameričkog zakonskog uređenja mogle bi se adaptirati i u hrvatski ZOZ.

U Sjedinjenim Američkim Državama, sve donedavno, nedostatak adekvatnog zakonskog mehanizma otežavao je strankama da osiguraju imovinska sredstva za uzdržavanje svojih ljubimaca nakon smrti. ${ }^{67},{ }^{68}$ Tako je case law u Sjedinjenim Američkim Državama prihvatio pristup da raspolaganje u korist životinje ne stvara zakladu koja se može prisilno provoditi, odnosno, upravitelj zaklade nije pod obvezom i ne može ga se prisiliti da imovinu upotrebljava za skrb o životinji. ${ }^{69}$ Štoviše, sudovi su uobičajeno držali da je ostavina u korist kućnog ljubimca protivna "pravilu protiv trajnosti" (rule against perpetuities), kao pravila common lawa, koje onemogućuje da se pravni instituti (prije svega, oporuke) upotrebljavaju radi kontrole nad imovinom nakon smrti osobe, odnosno, sprječava osobu da u oporuku unosi odredbe kojima će i dalje utjecati na vlasništvo nad imovinom dugo nakon što je umrla. "Pravilo protiv trajnosti" određuje da interes nad imovinom mora prestati najkasnije 21 godinu nakon smrti. ${ }^{70}$ Budući da određeni kućni ljubimci (papige, kornjače i dr.) mogu živjeti i 50 godina nakon smrti svoga vla-

65 Tradicionalno, common law sustav također nije prihvaćao zakladu u korist životinje budući da u tom slučaju ne postoji fizička ili pravna osoba koja bi bila korisnik koji može ostvarivati cilj zaklade. Međutim, sudovi, zakonodavci i znanstvena zajednica, posebno u Sjedinjenim Američkim Državama, prihvatila je širok spektar pristupa pitanju upotrebe imovine ostavitelja radi osiguravanja skrbi za životinju nakon njegove smrti. Beyer, Gerry W., Pet Animals: What Happens When Their Humans Die?, Santa Clara Law Review, Vol. 40, No. 3, 2000., str. 620.

66 U Sjedinjenim Američkim Državama u porastu je broj osoba koje posjeduju životinje. Oko 33,9 milijuna kućanstava ima psa, a oko 28,3 milijuna ima mačku. Uz te tradicionalne ljubimce, Amerikanci također posjeduju širok spektar drugih životinja. Naprimjer, jedanaest milijuna kućanstava ima ribe, šest milijuna ptice, pet milijuna male životinje kao što su hrčci ili zečevi i tri milijuna reptile. Ibid., 618. Zenov, I., Darin, Ruiz-Gonzalez, Barbara, Trust for Pets, The Florida Bar Journal, Vol. 79, No. 11, 2005., str. 2.

68 Common law sudovi u Engleskoj poznaju oporučne odredbe u korist određene životinje već više od stoljeća. Međutim, u početku sudovi nisu bili skloni takvom pristupu. Tako u predmetu Attorney General v. Whorwood iz 1750. sud izriče da sudovi ne bi trebali priznavati raspolaganja koja predstavljaju "neobične" (odd) ili "kapriciozne" (whimsical) darove, kao što su darovi za hranjenje vrabaca. Beyer, op. cit. (bilješka 65), str. 620. 
snika, zaklade u korist takvog ljubimca povrjeđivale bi "pravilo protiv trajnosti". ${ }^{71},{ }^{72}$ Međutim, 1990. godine izmijenjen je Jednoobrazni zakon o nasljeđivanju ${ }^{73}$ (Uniform Probate Code). To je predstavljalo znatan napredak u prihvaćanju zaklade za dobrobit kućnih ljubimaca. Cilj je izmjena bio razgraničiti tretman zaklade za životinje od zaklada za sve ostale zakonske svrhe. ${ }^{74}$

Ovdje treba naglasiti da pojam trust u angloameričkom pravu nema preciznog ekvivalenta u pojmu zaklade u kontinentalnoeuropskom sustavu civilnog prava. Najbližu analogiju pojam trust, u sustavu civilnog prava, imao bi u pojmu "fondacija" (fondation u francuskom, ili Stiftung u njemačkom pravu) kada se odnosi na zaklade formirane u dobrotvorne svrhe. ${ }^{75}$ Pojam trust common law sustava može se prevesti kao "financijski fond povjerenja", ili "pravni odnos u kojem neka osoba ima interes u imovini koja nominalno pripada drugoj osobi". ${ }^{76}$ Institut trust ima velik praktični značaj u angloameričkom pravnom sustavu i upotrebljava se u širokom kontekstu značenja, ali ipak najznačajnija upotreba je u uređenju obiteljskih odnosa i u dobrotvornim darivanjima. U tom smislu, najčešći oblik zaklade u common law sustavu jest privatna zaklada kao sredstvo za ostvarivanje financijske sigurnosti obitelji. Oporučno, ostavitelj imovinu ostavlja zakladi u cilju skrbi za obitelj nakon njegove smrti. Upravitelj zaklade investira sredstva zaklade kako bi omogućio redovite isplate nasljednicima. Javne zaklade osnivaju se u cilju ostvarivanja koristi za širi krug osoba ili ostvarenja šireg opsega koristi. Najčešće javne zaklade su dobrotvorne zaklade. Zaklade koje nisu dobrotvornog karaktera služe podupiranju društvenih grupa za zajedničkim interesima, profesionalnih ili društvenih grupa. Moderni sustavi civilnog prava, kao što je meksički, stvaraju institute kao što je trust na način da prilagođavaju ideje iz angloameričkog pravnog sustava. ${ }^{77}$

Spomenute zakonske izmjene u Sjedinjenim Američkim Državama prilagodile su institut zaklade zaštiti dobrobiti kućnih ljubimaca. Tako se upravitelju zaklade zabranjuje upotrebljavati glavnicu ili prihode zaklade u bilo koju drugu svrhu osim u korist životinje. Upravljanje zakladom može se prisilno provoditi, a vlasnik životinje može odrediti osobu s ovlaštenjem da provodi upravljanje zakladom. Ako ju ne odredi vlasnik životinje, svatko je ovlašten zahtijevati od suda da to učini. Vlasnik životinje mora biti oprezan kako ne bi odredio previše imovine za skrb o životinji. Sud može smanjiti iznos imovine prenesen na zakladu ako zaključi da iznos u znatnoj mjeri premašuje potrebe skrbi za životinju. Administrativne odgovornosti upravitelja zaklade znatno su smanjene. Ako sud ili zaklada ne odluči drukčije, nisu potrebni izvještaji, registracije, periodično računovodstvo. Osim što može imenovati upravitelja zaklade, sud može odrediti i sve drugo potrebno kako bi se ostvarile želje vlasnika životinje. Ukinuto je ograničenje trajanja zaklade na 21 godinu pa vlasnici životinja s dugim životnim vijekom mogu koristi-

71 Ibid.

72 Također, problem je postojao u vezi s porezom na dohodak zaklade. Porezna služba nije kao korisnika priznavala kućnog ljubimca, pa zaklada nije mogla biti oporezovana. Skrbnik životinje nije mogao biti obvezan poreznom odgovornošću budući da je imao samo ulogu zastupnika životinje i ne troši doprinose u svoju korist. To je stvorilo lukrativnu poreznu rupu jer nitko ne bi imao obvezu plaćanja poreza na dohodak zaklade. Porezna služba je brzo prepoznala problem i izmjenama propisa određeno je da će zaklada za kućnog ljubimca biti oporezovana na sve svoje prihode, bez obzira na potrošnju učinjenu u korist životinje korisnika. Ibid., str. 4.-5.

Uniform Probate Code, 1969., http://www.uniformlaws.org/shared/docs/probate\%20code/upc\%202010.pdf, pristupljeno 4. listopada 2018., u daljnjem tekstu UPC.

Beyer, op. cit. (bilješka 65), str. 650. 
ti odredbe ovog Zakona kako bi zaklada pribavila sredstva za skrb nad njihovim životinjama. Većina saveznih država prihvatila je ovakvo zakonsko uređenje s manjim ili većim razlikama (potreba registriranja zaklade, sudsko određivanje iznosa potrebnog za skrb za životinju i dr.). Tako Kalifornija npr. ograničava trajanje zaklade na životni vijek životinje te vlasnik ne može u skrb uključiti potomke životinje rođene nakon smrti vlasnika životinje. ${ }^{78}$

Zbog različitog zakonskog uređenja u saveznim državama u praksi se javljaju različite preporuke za formuliranje oblika skrbi za životinju preko zaklade. ${ }^{79}$ Tako se naglašava da vlasnik treba individualizirati životinju informacijama o vrsti, lokaciji na kojoj boravi, posebnim karakteristikama ili mikročipiranjem kako bi se izbjegle prijevare (npr. kako se ne bi zamijenila izgubljena ili preminula životinja). Upravitelj zaklade trebao bi obilaziti životinju kako bi se uvjerio u kakvim uvjetima životinja živi. Najpouzdaniji način za ostvarenje skrbi za životinju jest da se formira oporučna zaklada u korist ljudskog korisnika i tada zahtijeva da upravitelj vrši dodjelu sredstava korisniku za pokriće troškova koje korisnik zaklade ima za skrb nad životinjom. Vlasnik bi trebao imenovati nekoliko alternativnih skrbnika za životinju ako onaj koji je prvi izbor ne može pružati skrb za cijelog života životinje. Vlasnik životinje treba pozorno odrediti iznos potreban za skrb za životinju, ovisno o vrsti životinje, očekivanom životnom vijeku, standardu skrbi. Pri tome treba izbjegavati prevelike iznose kako se ne bi potaknuli nasljednici da pobijaju oporučne odredbe o zakladi. Treba i specificirati način na koji će upravitelj dodjeljivati sredstva osobi koja pruža skrb (plaćanje fiksnog iznosa bez obzira na troškove skrbi, naknađivanje specificiranih troškova za određene potrebe životinje itd.). Vlasnik životinje treba odlučiti hoće li formirati inter vivos ili oporučnu zakladu. Zaklada inter vivos odmah je djelotvorna i time se otklanjaju odgode djelovanja zaklade nakon smrti vlasnika životinje. S druge strane, ove zaklade mogu imati troškove za početak djelovanja i administrativne izdatke. ${ }^{80}$

\subsection{UGOVORI S NASLJEDNOPRAVNIM UČINCIMA}

Ugovaranje nasljednopravnih učinaka nije dopušteno u većini suvremenih pravnih poredaka. ${ }^{81}$ Međutim, ZN-om uređuje se ugovor o ustupanju i raspodjeli imovine za života koji predstavlja pravni posao inter vivos i proizvodi određene nasljednopravne učinke. ${ }^{82},{ }^{83}$ To je ugovor kojim "predak (ustupitelj) razdjeljuje i ustupa potomcima cjelokupnu ili dio svoje imovine". ${ }^{84}$

78 Beyer, op. cit. (bilješka 65), str. 351.-663.

79 U međuvremenu, pravo životinja je u Sjedinjenim Američkim Državama postalo područje odvjetničke prakse koje se naglo širi. Javljaju se odvjetničke tvrtke koje se bave pravom životinja u odnosu na planiranje upravljanja imovinom za životinje $i$ rješavanjem sporova u vezi sa životinjama. Širi se broj tvrtki koje se bave pružanjem skrbi za cijeli život životinje nakon smrti vlasnika s različitim programima (medicinska zaštita, hranjenje, njega i sl.). Zenov et al., op. cit. (bilješka 67), str. 6.

$80 \quad$ Beyer, op. cit. (bilješka 65), str. 663.-676.

81 Gavella et al., op. cit. (bilješka 1), str. 421.

82 "Do stupanja na snagu ZOO-a, 1. siječnja 2006. godine, ZN je uređivao i ugovor o doživotnom uzdržavanju koji je, zapravo, ugovor obveznopravne prirode o otuđenju imovine uz naknadu gdje je predaja imovine davatelju uzdržavanja odgođena do smrti primatelja uzdržavanja." Klarić et al., op. cit. (bilješka 39), str. 511.

83 Budući da ugovor o doživotnom uzdržavanju nije ugovor o nasljeđivanju, nego obveznopravni ugovor, neće ni biti predmet analize ovoga rada. Isto vrijedi i za ugovor o dosmrtnom uzdržavanju kao i za darovanje za slučaj smrti. 
Ugovor o ustupu i raspodjeli imovine za života može biti naplatan pravni posao kojim predak zadržava određena prava u prigodi ustupa i raspodjele, odnosno kojim su potomci i/ili bračni drug ${ }^{85}$ preuzeli na sebe kakve obveze prema pretku. ${ }^{86}$ Tako, naprimjer, ustupitelj bi mogao "za sebe, svog bračnog druga ili drugu osobu odrediti osnivanje osobne služnosti, stvarnog tereta na predmetima ustupanja, ugovoriti doživotnu rentu u naravi ili novcu, ugovoriti doživotno uzdržavanje ili drugu naknadu" ${ }^{87} \mathrm{U}$ tom smislu, bilo bi moguće da ustupitelj ugovori davanje skrbi za kućnog ljubimca ili drugu životinju od strane potomaka ili bračnog druga, a nakon smrti ustupitelja. Moguće je uočiti sličnost sa spomenutim ugovorom o doživotnom uzdržavanju. Razlika je u tome da "pri sklapanju ugovora o ustupu i raspodjeli imovine za života, ustupitelj odmah prenosi pravo vlasništva na imovini na potomka (i bračnog druga), dok kod sklapanja ugovora o doživotnom uzdržavanju, vlasništvo na davatelja uzdržavanja prelazi tek u času smrti primatelja uzdržavanja" ${ }^{88}$ Odmah upada u oči da mogućnost ostvarenja skrbi za životinju, nakon smrti ustupitelja, ovisi o benevolenciji potomka, odnosno bračnog druga jer nedostaje zakonski mehanizam prinudnog ostvarivanja preuzete obveze. Eventualno, ustupitelj bi mogao zasnovati pravo iz stvarnog tereta u korist osobe koja će pružati skrb za životinju. Opterećenik stvarnim teretom tada bi bio potomak i/ili bračni drug kao vlasnik nekretnine koju je stekao ugovorom o ustupu i raspodjeli imovine za života. ${ }^{89}$ Najučinkovitiji bio bi personalni, novčani, stvarni teret u korist pojedinca, a koji je pravnim poslom kojim je stvarni teret osnovan određen kao osoba obvezna da skrbi o određenoj životinji. Stvarni teret osniva se uknjižbom na nekretnini koja se njime opterećuje. ${ }^{90}$ Svakako da glavno ograničenje u primjeni ovog instituta proizlazi iz okolnosti da predmet stvarnog tereta može biti samo nekretnina. Ako ugovor o ustupu i raspodjeli imovine za života nema za svoj predmet raspolaganje nekretninama u vlasništvu ustupitelja, ne bi bilo moguće ni osnovati stvarni teret kao mehanizam posrednog raspolaganja imovinom u korist životinje.

\section{ZAKLJUČAK}

Pravni poredak ograničavanje načela dispozitivnosti u nasljednom pravu temelji se na pretpostavci da osobe s kojima je ostavitelj bio u najčvršćim obiteljskim i emotivnim odnosima trebaju biti ostaviteljevi nasljednici. Individualizam današnjice traži da razmotrimo i druge mogućnosti u raspolaganju imovinom za slučaj smrti pojedinca. Socijalne i emotivne veze koje suvremeni čovjek razvija prema životinjama, posebno kućnim ljubimcima, evoluirale su tije-

85 "Ustupitelj može ustupom i raspodjelom obuhvatiti i bračnog druga. Tada je potrebno da se i on suglasi s ugovorom. Ukoliko bračni drug ne bude obuhvaćen ugovorom, ustup i raspodjela imovine bit će valjani. Međutim, tada će se za utvrđivanje vrijednosti nužnog dijela, imovina koja je razdijeljena i ustupljena biti smatrana darom." Ibid.

86 Hrvatin, Branko, Nasljednopravni ugovori, u: Crnić, Jadranko, Dika, Mihajlo, Hrvatin, Branko, Jelčić, Olga, Josipović, Tatjana, Ruždjak, Jožica Matko, Koharić, Zdenka, Novo nasljednopravno uređenje, (opća redakcija Dika, Mihajlo), Narodne novine, Zagreb, 2003., str. 130.

87 Ibid., str. 141.

88 Ibid., str. 142.

89 Opterećenik će biti i svagdašnji vlasnik opterećene nekretnine, dakle, onaj koji bi stekao tako stvarnim teretom opterećenu nekretninu od potomka i/ili bračnog druga. Gavella, Nikola, Tatjana, Josipović, Gliha, Igor, Belaj, Vlado, Stipković, Zlatan, Stvarno pravo, svezak drugi, Narodne novine, Zagreb, 2007., str. 47. 
kom stoljeća. Tendencije uređenja raspolaganja imovinom u korist životinje za slučaj smrti ostavitelja javljaju se u suvremenim pravnim porecima i pitanje je trenutka kada će doći do potrebe njihove pravne regulacije i u hrvatskom nasljednom pravu.

Na temelju aktualnog zakonskog uređenja životinja ne predstavlja pravni subjekt te ne bi mogla biti ni oporučni nasljednik ni zapisovnik. Nalog, kao dužnost osobe ispuniti određenu činidbu na temelju vrijednosti onoga što se steklo na osnovi raspolaganja oporučitelja, mogao bi sadržavati obvezu davanja određenih sredstava osobi koja bi se skrbila za životinju nakon smrti oporučitelja. Međutim, nema efikasne zakonske mogućnost da se traži ispunjenje naloga od osobe opterećene nalogom. Ipak, de lege lata, nalog predstavlja jedini mehanizam koji omogućuje da se u hrvatskom pravnom sustavu izvrši nasljednopravno raspolaganje u korist životinje.

Formiranje zaklade oporučnom odredbom koja bi imala za svrhu skrb za određenu životinju nakon smrti oporučitelja, prema ZN-u predstavlja dopušten način oporučnog raspolaganja. Riječ je o tzv. nesamostalnoj zakladi koja nije pravni subjekt, nego pripada određenoj fizičkoj ili pravnoj osobi i predstavlja određeni fond imovine koji je osoba obvezna koristiti samo u svrhu koju je odredio oporučitelj. I u ovom slučaju problem je faktična nemogućnost prisilnog ostvarenja ako osoba kojoj je povjereno ispunjenje svrhe zaklade to ne želi dobrovoljno izvršavati. Osnivanje samostalne zaklade oporučnom odredbom, prema odredbama ZOZ-a, ne bi bilo moguće u cilju da se imovina ostavitelja namjeni skrbi i uzdržavanju individualno određene životinje budući da se time ne unaprjeđuje određena društvena djelatnost, odnosno materijalno stanje društva. Također, ZOZ kao dobrotvornu svrhu određuje samo onu kojom se potpora pruža osobama. Ugovor o ustupu i raspodjeli imovine za života može biti naplatan pravni posao kojim predak zadržava određena prava u prigodi ustupa i raspodjele, odnosno kojim su potomci i/ili bračni drug preuzeli na sebe kakve obveze prema pretku. U tom smislu, bilo bi moguće da ustupitelj ugovori davanje skrbi za kućnog ljubimca ili drugu životinju od strane potomaka ili bračnog druga, a nakon smrti ustupitelja. Odmah upada u oči da mogućnost ostvarenja skrbi za životinju nakon smrti ustupitelja, ovisi od benevolencije potomka, odnosno bračnog druga jer nedostaje zakonski mehanizam prinudnog ostvarivanja preuzete obveze. Eventualno, ustupitelj bi mogao zasnovati pravo iz stvarnog tereta u korist osobe koja će pružati skrb za životinju. Svakako da glavno ograničenje u primjeni ovog instituta proizlazi iz okolnosti da predmet stvarnog tereta može biti samo nekretnina.

Komparativna analiza uređenja raspolaganja ostavinom u obliku zaklade ukazala je na smjer zakonskih intervencija u ZN-u i ZOZ-u koje bi de lege ferenda predstavljale mogućnost ostvarenja nasljednopravnih raspolaganja u korist životinje. To bi predstavljalo prihvaćanje zaklade za dobrobit kućnih ljubimaca. Zakonske izmjene imale bi za cilj razgraničenje tretmana zaklade za životinje od zaklada za sve ostale zakonske svrhe. U tom smislu, bilo bi potrebno zakonski predvidjeti ulogu suda ili sudskog povjerenika u upravljanju zakladom, a i ovlast vlasnika životinje koji može odrediti osobu s ovlaštenjem da provodi upravljanje zakladom. Najpouzdaniji način za ostvarenje skrbi za životinju jest da se formira oporučna zaklada u korist ljudskog korisnika i tada zahtijevati da upravitelj vrši dodjelu sredstava korisniku za pokriće troškova koje korisnik zaklade ima za skrb nad životinjom. Vlasnik životinje treba odlučiti hoće li formirati inter vivos ili oporučnu zakladu. Zaklada inter vivos je odmah djelotvorna i time se otklanjaju odgode djelovanja zaklade nakon smrti vlasnika životinje. 
Ovakvo zakonsko uređenje korespondiralo bi s tendencijama omogućavanja nasljednopravnih raspolaganja imovinom u korist životinje u suvremenim pravnim porecima. Novim pristupom u zakonskom uređenju uklonile bi se nepravde dosadašnje paradigme koja je onemogućavala slobodu raspolaganja imovinom za slučaj smrti u korist onih bića koja su čovjeku pružala ljubav i utjehu tijekom života.

\section{LITERATURA}

\section{KNJIGE I ČLANCI}

1. Bearup, J. Brooke, Pets: Property and the Paradigm of Protection, Journal of Animal Law, Vol. III, Michigan State University College of Law, 2007.

2. Beyer, Gerry W., Pet Animals: What Happens When Their Humans Die?, Santa Clara Law Review, Vol. 40, No. 3, 2000.

3. Foster, H. Frances, Should Pets Inherit?, Florida Law Review, Vol. 63, Issue 4, 2011.

4. Foster, H. Frances, The Family Paradigm of Inheritance Law, North Carolina Law Review, Vol. 80, No. 1, 2001.

5. Gačić, Milica, Englesko-hrvatski rječnik prava i međunarodnih i poslovnih odnosa, Školska knjiga, Zagreb, 2010.

6. Gary, N. Susan, Adapting Intestacy Laws ot Changing Families, Law \& Inequality: A Journal of Theory and Practice, Vol. 18, Issue 1, 2000.

7. Gavella, Nikola, Belaj, Vlado, Nasljedno pravo, Narodne novine, Zagreb.

8. Gavella, Nikola, Josipović, Tatjana, Gliha, Igor, Belaj, Vlado, Stipković, Zlatan, Stvarno pravo, Svezak drugi, Narodne novine, Zagreb, 2007.

9. Gavella, Nikola, Josipović, Tatjana, Gliha, Igor, Belaj, Vlado, Stipković, Zlatan, Stvarno pravo, Narodne novine, Zagreb, 2007.

10. Hrvatin, Branko, Nasljednopravni ugovori, u: Crnić, Jadranko, Dika, Mihajlo, Hrvatin, Branko, Jelčić, Olga, Josipović, Tatjana, Ruždjak, Jožica Matko, Koharić, Zdenka, Novo nasljednopravno uređenje, (opća redakcija Dika, Mihajlo), Narodne novine, Zagreb, 2003.

11. Klarić, Petar, Vedriš, Martin, Građansko pravo, Narodne novine, Zagreb, 2006.

12. Kontrec, Damir, Matko-Ruždjak, Jožica, Sessa Đuro, Zakon o nasljeđivanju s komentarima, poveznicama, sudskom praksom, prilozima, primjerima i abecednim kazalom pojmova, Organizator, Zagreb, 2005.

13. Milić, Ivo, Oko postanka oporuke, Jugoslavenska akademija znanosti i umjetnosti, Zagreb, 1951.

14. Nedić, Tomislav, Pravni sustav zaštite života, zdravlja - bioetički pristup u pravnom okviru, Socijalna ekologija: časopis za ekološku misao i sociologijska istraživanja okoline, Vol. 27, No. 1., 2018.

15. Romac, Ante, Rimsko pravo, Narodne novine, Zagreb, 1992.

16. Romac, Ante, Rječnik rimskog prava, Informator, Zagreb, 1989.

17. Roukas, S. Marcella, Determining the Value of Companion Animals in Wrongful Harm or Death Claims: A Survey of U.S. Decisions and Legislative Proposal in Florida to Authorize Recovery for Loss of Companionship, Journal of Animal Law, 3, Michigan State University College of Law, 2007.

18. Stojanović, Nataša, Pravo životinja, Pravni fakultet Univerziteta, Centar za publikacije, Niš, 2017. 
19. The New Encyclopaedia Britannica, Micropaedia, Encyclopaedia Britannica Inc., Chicago, Volume 12, 1998.

20. Visković, Nikola, Angloamerički animal law, Zbornik radova Pravnog fakulteta u Splitu, 2/1993.

21. Vodinelić, V. Vladimir, Građansko pravo - Uvod u građansko pravo i Opšti deo građanskog prava, Pravni fakultet Univerziteta Union u Beogradu, Beograd, 2012.

22. Zenov, I., Darin, Ruiz-Gonzalez, Barbara, Trust for Pets, The Florida Bar Journal, Vol. 79, No. 11, 2005.

\section{VAŽNIJE MREŽNE STRANICE KORIŠTENE KAO IZVORI}

1. http://www.uniformlaws.org.

2. https://scholarship.law.ufl.ei.

\section{PRAVNI IZVORI}

\section{A) Hrvatsko pravo}

1. Kazneni zakon, Narodne novine, broj 125/2011, 144/2012, 56/2015, 61/2015, 101/2017.

2. Zakon o nasljeđivanju, Narodne novine, broj 48/2003, 163/2003, 35/2005, 127/2013, 33/2015.

3. Zakon o nasljeđivanju, Službeni list FNRJ, broj 20/1955, Službeni list SFRJ broj 12/1965, 42/1965 - pročišćeni tekst, 44/1965, i 47/1965, Narodne novine broj 52/1971, 52/1973, 47/1978.

4. Zakon o obveznim odnosima, Narodne novine, broj 35/2005, 41/2008, 125/2011, 78/2015, 29/2018.

5. Zakon o vlasništvu i drugim stvarnim pravima, Narodne novine, broj 91/1996, 68/1998, 137/1999, 22/2000, 73/2000, 129/2000, 114/2001, 79/2006, 146/2008, 38/2009, 143/2012, 152/2014, 81/2015 (pročišćeni tekst), 94/2017 (pročišćeni tekst).

6. Zakon o zakladama i fundacijama, Narodne novine, broj 36/1995, 64/2001.

7. Zakon o zakladama, Narodne novine, broj 106/2018.

8. Zakon o zaštiti životinja, Narodne novine, broj 102/2017.

\section{B) Strani pravni izvori}

1. Allgemeines bürgerliches Gesetzbuch, JGS, Nr. 946/1811.

2. Bürgerliches Gesetzbuch, 1896.

3. Uniform Probate Code, 1969. 
82

Davorin Pichler

\section{TESTAMENTARY DISPOSITIONS ON BEHALF OF ANIMALS}

\section{Summary}

This paper researches into the possibilities of testamentary dispositions on behalf of animals in the case of death. There are certain tendencies regarding these issues in contemporary legal systems and it is only the question of time when the need for their legal regulation in Croatian inheritance law will arise. The institutes of inheritance law de lege lata have been analyzed, which may represent a mechanism for disposing of property in favour of an animal in the case of death of a testator. It points to the need for legal intervention in the Law on Succession and the Law on Foundations that would enable the establishment of a testamentary foundation in favour of a human beneficiary while the fund manager would allocate funds to the beneficiary to cover the costs that the beneficiary has in order to care for the animal.

Keywords: $\quad$ inheritance law, modus, foundation, animal, pet, testament

\section{(c) (i) (8)}

This work is licensed under a Creative Commons

Attribution-NonCommercial 4.0 International License.

* Davorin Pichler, PhD, Assistant professor, Faculty of Law, University of Osijek, Stjepana Radića 13, 31000 Osijek, Republic of Croatia. Email address: dpichler@pravos.hr. ORCID: https://orcid.org/0000-0002-0068-3601. 